\title{
Evaluation of the effect of twin births on the perinatal calf mortality and productive performance of Holstein dairy cows
}

\author{
NAVID GHAVI HOSSEIN-ZADEH
}

Department of Animal Science, Faculty of Agriculture, University of Guilan, Rasht, Iran

\begin{abstract}
Calving records from the Animal Breeding Center of Iran collected from January 1993 to December 2007 and comprising 1163594 Holstein calving events from 2552 herds were used to evaluate reported perinatal calf mortality, 305-d milk yield, 305-d fat yield of milk and 305-d fat percentage of milk in single- and twin-births. A logistic regression model was constructed to analyze calf mortality between singletons and twins. Also statistical analyses of 305-d milk yield, 305-d fat yield of milk and 305-d fat percentage of milk were performed using the general linear models procedure. Greater odds of calf mortality existed for calves born from primiparous cows than from multiparous cows $(P<0.001)$ and for calves born as twins than singletons. The odds of calf mortality increased over years from $4.2 \%$ in calving year $Y 1$ (1993-1997) to $5.1 \%$ in calving year Y3 (2003-2007) (odds ratio $[O R]=1.14 ; P<0.001)$. The odds of calf mortality was greater after twin births, with $16.7 \%$ of the twin calving events reporting calves as dead compared to $5.2 \%$ for singleton births $(\mathrm{OR}=5.62 ; P<0.001)$. For same-sex twin pairs, the odds of calf mortality was greater $(P<0.01 ; \mathrm{OR}=1.72)$ for male than for female twin pairs. Also, twin-calved cows had greater 305-d milk production, fat yield and fat percentage of milk than single-calved cows $(P<0.05)$. In general, development of practical management strategies to cope with the negative effects associated with twinning on dairies is critical, especially if the trend toward increased twinning in the dairy cattle population continues.
\end{abstract}

Keywords: Holstein dairy cow, twinning, calf mortality, milk performance

\section{Zusammenfassung}

\section{Auswirkungen von Zwillingsgeburten auf die perinatale Kälbersterblichkeit und die Milchleistung von Holstein Kühen}

Ausgewertet wurden Daten von 1163594 Kalbungen von Holstein Kühen aus 2552 Herden welche im Iranischen Tierzuchtzentrum im Zeitraum Januar 1993 bis Dezember 2007 erfasst wurden. Bewertet wurden die Merkmale perinatale Kälbersterblichkeit, 305Tage Milchertrag, 305-Tage Fettertrag und -anteil bei Einzel- und Zwillingsgeburten. Für die Analyse der Kälbersterblichkeit wurde ein logistisches Regressionsmodell genutzt, und die Analyse der Milchleistungsmerkmale erfolgte mit Hilfe des allgemeinen linearen Modells. Eine signifikant höhere Kälbersterblichkeit ergab sich sowohl bei erstgebärenden Kühen als auch bei Zwillingskälbern. Die Quote der Kälbersterblichkeit 
zeigte einen Anstieg im Untersuchungszeitraum. Sie betrug im Zeitraum 1993-1997 4,2\% und 2003-2007 5,1\%. Bei Zwillingsgeburten fanden sich höhere Sterblichkeitsquoten und diese betrugen 16,7\% gegenüber Einlingsgeburten mit nur 5,2\%. Gleichgeschlechtliche Zwillingspaare wiesen vor allem bei männlichen Kälbern eine höhere Sterblichkeit auf. Zwillingsmütter erreichten einen signifikant höheren Milchertrag, Fettertrag und -anteil als Einlingsmütter. Managementstrategien sollten die negativen Auswirkungen von Zwillingsgeburten berücksichtigen, zumal ein positiver Trend einer Zunahme von Zwillingsgeburten in Milchrindpopulationen in dieser Studie zu beobachten war.

Schlüsselwörter: Holstein Kuh, Zwillingsgeburten, Kälbersterblichkeit, Milchleistung

\section{Introduction}

Ovaries of cattle contain two different pools of follicles, the non-growing pool and the growing pool. The non-growing pool contains the primordial follicles, whereas the growing pool contains the primary, secondary and tertiary follicles. Entry of primordial follicles into the growth phase occurs throughout the reproductive life (KANITZ et al. 2001).

Cattle are a monotocous species meaning that, under most circumstances, a successful pregnancy results in the birth of a single calf. The physiologic mechanism responsible for regulating the number of follicles that become dominant within each follicular wave usually results in selection of a single dominant follicle capable of ovulation. If luteolysis occurs during the growth phase of dominant follicles, final maturation and ovulation occurs. If luteolysis does not occur during the growing and maintenance phase of follicles, the fate is atresia (KANITZ 2003, MATTIOLI 1996). Initiation of an induced or naturally occurring ovulatory stimulus causes release of a single oocyte from the dominant follicle at ovulation. If the subsequent events from fertilization to parturition occur normally, the pregnancy will result in birth of one calf. On occasion, however, two follicles are selected to continue growth from among the group of growing follicles in a follicular wave resulting in a phenomenon termed codominance. If the appropriate stimulus for ovulation occurs naturally or is induced when codominant follicles are present, two oocytes, one from each follicle, will be released. If the subsequent events from fertilization to parturition occur normally for both oocytes, twins will result (RYAN and BOLAND 1991).

Twinning in dairy cattle is an unavoidable outcome of reproduction and occurs relatively rarely, with the frequency generally not exceeding $1 \%$ in most beef herds. However, in dairy herds, the incidence of twin births is higher (on average 3 to $5 \%$ ), and is strongly affected by age and parity of the dam (GHAVI HOSSEIN-ZADEH et al. 2008, SILVA DEL RíO et al. 2007, KOMISAREK and DORYNEK 2002, WOLLERT and TILSCH 1988).

However, twin birth is disadvantageous for most beef and dairy producers because of its association with a number of unfavourable effects, including lower potential calf survival and poorer cow reproductive performance (FRICKE 2001). Twinning reduces reproductive performance by increasing average days open and services per conception during the subsequent lactation (FRICKE 2001). Twinning is also associated with increased dystocia (because of malpresentation), greater incidence of abortion, increased likelihood of culling for dams giving birth to twins, decreased fertility rate, greater 
frequency of stillbirth, increased incidence of retained placenta, higher mortality rates, frequent occurrence of freemartins and longer interval from parturition to first oestrus (KIRKPATRICK 2002, SILVA DEL RíO et al. 2007). Also, GÖRLICH et al. (1989) reported the number of beef calves from twinnings was by about $55 \%$ higher than from single calvings although peri-and postnatal calf losses were about $16 \%$ higher in twin calves.

The results of numerous surveys and studies have generally been consistent in identifying problems associated with twinning except for dystocia. Inconsistent results for incidence of dystocia may reflect two competing dynamics: twinning reduces incidence of dystocia attributable to large calf size but increases incidence of dystocia attributable to malpresentation (KIRKPATRICK 2002). Dairy cows may give more milk in the lactation resulting from a twin birth (SYRSTAD 1974), but cows calving twins are at greater risk for metabolic disorders including displaced abomasum, and ketosis (FRICKE 2001). In addition, increased frequency of twinning would increase the potential for obtaining more progeny from a genetically-superior female, thereby allowing those females to play a larger role in a selection program (CADY and VAN VLECK 1978). The importance of this condition can be expressed along with the application of technologies controlling the sex of calves.

The objective of this study was to analyze incidences of perinatal calf mortality recorded in Holstein dairy cows to make comparisons between singleton and twin births regarding several factors influencing the odds of calf mortality. Comparisons were also made for the potential effect of the incidence of twin births on the productive performance between twin and single births.

\section{Material and methods}

\section{Data set}

Calving records from the Animal Breeding Center of Iran, collected from January 1993 to December 2007 and comprising 1163594 Holstein calving events from 2552 herds were included in the initial data set. Twin calvings accounted for $32082(2.76 \%)$ of the total observations. The majority of the Iranian dairy cattle population consists of several domestic breeds and their crosses with Holstein. Only about 800000 head are purebred Holsteins. These are either descendants of the cows originally imported from North America and Europe or Holstein upgrades of domestic breeds over 50 years. The herds used in this study are among the purebred Holsteins managed under conditions similar to those in most other developed countries. The herds are under official performance and pedigree recording. Artificial insemination is used almost exclusively; and $60 \%$ to $80 \%$ of semen is from US and Canadian proven sires (GHAVI HOSSEIN-ZADEH et al. 2008). Information for individual calving events, including herd, cow identification, service sire identification, cow's sire identification, calving date, dry date, parity, multiple births, calf gender, calf mortality, 305-d milk yield, fat yield of milk, fat percentage of milk and calving difficulty were included in the data set. The number of calves born per calving event was coded as a dichotomous variable $\left(0=\right.$ singleton $\left[C_{1}\right] ; 1=$ twin $\left.\left[C_{2}\right]\right)$. Calf sex for singleton births was coded $M$ for males and $F$ for females, whereas calf sex for twin births was coded as MM for male pairs, FF for female pairs, and FM or MF for mixed-sex pairs. 
Perinatal calf mortality for singleton calves was coded as $A$ for calves born alive and $D$ for calves born dead, whereas for twin calves was coded as AA when both calves were born alive, DD when both calves were born dead, and DA when only one of the twin calves survived. Months of birth were grouped into four seasons: January through March (winter), April through June (spring), July through September (summer), and October through December (fall). Also, calving years were grouped into three classes: 1993 through 1997 (Y1), 1998 through 2002 (Y2), and 2003 through 2007 (Y3). First-parity cows (P1) represented 30.8\%, whereas second (P2), third (P3) and fourth and greater parities (P4) accounted for $25.1,17.6$ and $26.5 \%$ of the calving records, respectively.

\section{Statistical analyses}

A multivariable logistic regression model was used to analyze perinatal calf mortality using the maximum likelihood method of the LOGISTIC procedure of SAS (SAS INSTITUTE 2002). Model specification was based on the backward elimination method and the fit of all statistical models was evaluated by using the Hosmer and Lemeshow goodness-of-fit test of SAS (HOSMER and LEMESHOW 2000) by including the »lackfit" option in the model statement. Variables (main effects or interaction terms) which were significant by the Wald statistic at $P<0.05$ were included in the model. In addition, statistical analysis of milk yield, fat yield and fat percentage were performed using the general linear models procedure (Proc GLM) of SAS (SAS INSTITUTE 2002).

The general equation of logistic regression model is defined as follows:

$$
\operatorname{Logit}(\pi)=a+\beta_{1} X_{1}+\beta_{2} X_{2}+\cdots+\beta_{n} X_{n}
$$

where $\pi$ is the the odds of perinatal calf mortality; $a$ is the intercept parameter; $\beta_{1}$ to $\beta_{n}$ are the logistic regression coefficients (parameter estimates) for the explanatory effects $\left(X_{1}\right.$ to $\left.X_{n}\right)$ included in the statistical model.

Calf mortality for calves born as singleton was analyzed in a model in which the following variables were included: Herd, parity of dam, sex of the calf ( $M$ vs. F), calving year and parity by year interaction effect. The model used to analyze calf mortality for calves born as twins included the fixed class effects of Herd, Parity of dam and sex of the calf (MM, MF, and FF). Also, calf mortality for all calves was analyzed in a model in which the following variables were included: Herd, parity of dam, calf number (2 vs. 1), calving year, parity by year and calf number by parity interaction effects.

Milk yield, fat yield and fat percentage of milk were analyzed in a model in which the following variables were included: Herd, calving year, season of calving, parity of dam, calf number ( 2 vs. 1), parity by calf number and parity by year interaction effects, the linear and quadratic effects of age of dam as covariates. In addition, 305-d milk yield, fat yield and fat percentage of milk for single or twin births was analyzed in a model in which the following variables were included: herd, calving year, season of calving, parity of dam, and parity by year interaction effect. 


\section{Results and discussion}

\section{Perinatal mortality}

The overall incidence of perinatal calf mortality was $7.6 \%$ although it varied among herds from $1.2 \%$ to $15.7 \%$. This is similar to the perinatal mortality reported for dairy cattle in previous studies (SILVA DEL RíO et al. 2007, SIMENSEN 1982). There was an increase in singleton calf mortality as herd size increased $(P<0.05)$. Caution must be taken when interpreting the effect of herd size on perinatal calf mortality. One explanation for these results may be that individual cows are less intensively managed during calving in larger herds; however, larger herds represented in this data set may have more accurately reported calf mortality than smaller herds, or perhaps the effect is due to herd expansion rather than the effect of herd size itself.

Greater odds of calf mortality existed for calves born from primiparous cows than from multiparous cows $(P<0.001)$ and for calves born as singletons $(8.2 \%$ vs. $2.9 \%)$ or twins (29.4\% vs. $18.7 \%$; Tables 1 to 3). SILVA DEL RíO et al. (2007) reported greater perinatal mortality existed for calves born from nulliparous heifers than from lactating cows for calves born both as singletons and as twins. BICALHO et al. (2007) and MEYER et al. (2001) reported a significant decreasing trend in the incidence of stillbirth by parity in Holstein dairy cows. Perinatal calf mortality over time was defined by a significant parity by year interaction for singleton births $(P<0.001$; Tables 1 and 2$)$, but not for twin births (Table 3). SILVA DEL RíO et al. (2007) reported significant calf mortality for singletons but not for twins in Holstein dairy cows.

Table 1

Estimated odds ratios and their $95 \%$ confidence intervals, parameter estimates for the effects of parity of dam, calf number, and calving year on reported perinatal calf mortality for singleton and twin births of Holstein cows from 1993 to 2007

Sterblichkeitsquote und Konfidenzintervall für Laktationsnummer, Jahr und Kälberzahl von 1993 bis 2007

\begin{tabular}{lccccc}
\hline \multicolumn{1}{c}{ Effect } & Class & Estimate \pm SE & Odds ratio & $95 \% \mathrm{Cl}$ & $P$ \\
\hline Intercept & - & $-3.2 \pm 0.04$ & - & - & - \\
Parity of dam & 1 & - & 1 & - & $<0.001$ \\
& 2 & $-0.4 \pm 0.02$ & 0.34 & $0.30-0.47$ & - \\
& 3 & $-0.2 \pm 0.03$ & 0.31 & $0.27-0.35$ & - \\
Year & $=4$ & $-0.2 \pm 0.02$ & 0.39 & $0.36-0.43$ & - \\
& 1 & - & 1 & - & $<0.001$ \\
& 2 & $-0.1 \pm 0.02$ & 1.01 & $0.97-1.04$ & - \\
Calf number & 3 & $0.2 \pm 0.02$ & 1.14 & $1.09-1.20$ & - \\
& 1 & - & 1 & - & $<0.001$ \\
Calf number $\times$ Parity & 2 & $1.0 \pm 0.02$ & 5.62 & $4.82-6.35$ & - \\
& $\mathrm{C} 1-\mathrm{P} 1$ & - & 1 & - & $<0.001$ \\
& $\mathrm{C}-\mathrm{P} 2$ & $-0.5 \pm 0.06$ & 0.62 & $0.49-0.86$ & - \\
& $\mathrm{C} 2-\mathrm{P} 3$ & $-0.5 \pm 0.06$ & 0.68 & $0.56-0.81$ & - \\
& $\mathrm{C} 2-\mathrm{P} 4$ & $-0.7 \pm 0.04$ & 0.54 & $0.41-0.72$ & - \\
\hline
\end{tabular}

SE standard error, $\mathrm{Cl}$ confidence intervals 
Table 2

Estimated odds ratios and their $95 \%$ confidence intervals, parameter estimates for the effects of calving year, parity of dam, and sex of calf on reported perinatal calf mortality for singleton births of Holstein cows from 1993 to 2007

Sterblichkeitsquote nach Laktationsnummer Geschlecht und Jahr bei Einlingsgeburten von 1993 bis 2007

\begin{tabular}{lccccc}
\hline Effect & Class & Estimate $\pm \mathrm{SE}$ & Odds ratio & $95 \% \mathrm{Cl}$ & $P$ \\
\hline Intercept & - & $-2.8 \pm 0.04$ & - & - & - \\
Parity of dam & 1 & - & 1 & - & $<0.001$ \\
& 2 & $-0.4 \pm 0.03$ & 0.56 & $0.46-0.65$ & - \\
& 3 & $-0.2 \pm 0.04$ & 0.47 & $0.41-0.54$ & - \\
Sex & $>$ & $-0.3 \pm 0.03$ & 0.53 & $0.46-0.59$ & - \\
& $\mathrm{M}$ & $0.4 \pm 0.02$ & 2.87 & $2.54-3.25$ & $<0.001$ \\
Year & $\mathrm{F}$ & - & 1 & - & - \\
& 1 & - & 1 & - & 0.001 \\
& 2 & $0.1 \pm 0.02$ & 1.24 & $1.16-1.39$ & - \\
\hline
\end{tabular}

SE standard error, $\mathrm{Cl}$ confidence intervals

Table 3

Estimated odds ratios and their $95 \%$ confidence intervals $(\mathrm{Cl})$, parameter estimates for the effects of parity of dam and sex of calf on reported perinatal calf mortality for twin births of Holstein cows from 1993 to 2007

Sterblichkeitsquote nach Laktationsnummer und Geschlecht bei Zwillingsgeburten von 1993 bis 2007

\begin{tabular}{lccccc}
\hline Effect & Class & Estimate $\pm \mathrm{SE}$ & Odds ratio & $95 \% \mathrm{Cl}$ & $P$ \\
\hline Intercept & & $-1.8 \pm 0.08$ & - & - & - \\
Parity of dam & 1 & - & 1 & - & $<0.001$ \\
& 2 & $-0.3 \pm 0.09$ & 0.51 & $0.43-0.59$ & - \\
& 3 & $-0.4 \pm 0.09$ & 0.47 & $0.42-0.53$ & - \\
Sex & $>=4$ & $-0.2 \pm 0.10$ & 0.54 & $0.45-0.62$ & - \\
& FF & - & 1 & - & 0.001 \\
& MF & $0.1 \pm 0.10$ & 1.43 & $1.22-1.64$ & - \\
& MM & $0.3 \pm 0.10$ & 1.72 & $1.51-1.95$ & - \\
\hline
\end{tabular}

SE standard error, $\mathrm{Cl}$ confidence intervals

The odds of calf mortality increased over years from $4.2 \%$ in calving year $Y 1$ to $5.1 \%$ in calving year $\mathrm{Y} 3(\mathrm{OR}=1.14 ; P<0.001$; Table 1 ; $Y 3$ vs. $Y 1)$. HANSEN et al. (2004) reported the overall frequency of stillbirth in Danish Holsteins increased from 0.071 to 0.090 during 1985 to 2002 . The odds of calf mortality was greater after twin births, with $16.7 \%$ of the twin calving events reporting calves as DD or DA compared to $5.2 \%$ for singleton births ( $O R=5.62 ; P<0.001$; Table 1; twins vs. singletons). Also, there was a significant interaction effect between calf number and parity $(P<0.001)$. Consistent with our results, CADY and VAN VLECK (1978) and SILVA DEL RÍO et al. (2007) reported Calf mortality was greater after twin births in Holstein dairy cows. Previous studies of Holstein herds reported stillbirth rates for singleton births between 3.2\% and 5.4\%, and for calves born as twins between $12.9 \%$ and $15.7 \%$ (DAY et al. 1995, MEE 1991).

The overall reported singleton mortality differ significantly based on sex of the calf, with $6.9 \%$ vs. $3.1 \%$ for $M$ and $F$ calves, respectively $(P<0.001 ; O R=2.87$; Table $2 ; M$ vs. $F)$. For same-sex twin pairs, the odds of calf mortality was greater $(P<0.01 ; O R=1.72 ; M M$ vs. FF $)$ 
for $M(24.9 \%)$ than for $F(16.6 \%)$ twin pairs, whereas calf mortality for mixed-sex twins was $20.3 \%$ (Table 3). This effect is probably due to greater body size of male calves than female ones at birth. Similarly, previous studies reporting greater stillbirth rates among $\mathrm{M}$ twins (MEE 1991). Also, HEINS et al. (2006) reported male calves had significantly more stillbirths than heifer calves. SILVA DEL RÍO et al. (2007) reported the overall reported singleton mortality did not differ based on sex of the calf, but for samesex twin pairs, calf mortality was greater $(P<0.01)$ for $M(25.1 \%)$ than for $F(18.3 \%)$ twin pairs and calf mortality for mixed-sex twins was $20.3 \%$.

\section{Productive performance}

The Least-squares means and their standard errors for the 305-d milk yield, milk fat yield and milk fat percentage of Holstein dairy cows are shown in Table 4. The least-squares means of milk yield and fat yield were greater for the cows in their third lactation than other parities $(P<0.05$; Tables 5 and 6$)$. This time is concurrent with the peak of milk production in Iranian Holsteins. On the other hand, the least-squares means of fat percentage increased over the years for all calvings and for single births (Tables 4 and 5; $P<0.05)$. The phenotypic trend of milk yield and fat yield increased over the years from $\mathrm{Y} 1$ through $Y 3$, but this trend was decreasing for fat percentage $(P<0.05$; Tables 4 and 5$)$. In addition, fall-calved cows had the higher milk yield and fat yield than cows calved in the other seasons, but the fat percentages of milk of the summer-calved cows were greater than other cows $(P<0.05$; Tables 4 and 5$)$. There were significant parity by year and parity by calf number interaction effects for the 305-d milk yield, fat yield and fat percentage of dairy cows $(P<0.05)$. In addition, the interaction effect of parity by year was significant on the milk yield, fat yield and fat percentage of milk of singleton and twin births of Holstein dairy cows $(P<0.05)$. Also, twin-calved cows had greater $305-\mathrm{d}$ milk production, fat yield and fat percentage of milk than single-calved cows ( $P<0.05$; Tables 4 and 5$)$. In addition, the linear and quadratic effects of age of dam were significant on milk yield, fat yield and milk fat percentage $(P<0.05)$. The coefficients of regression and their standard errors of 305-d milk yield, milk fat yield and milk fat percentage on the linear and quadratic effects of age of dam are presented in Table 6. The linear coefficients of regression of milk yield, fat yield and milk fat percentage on age of dam were positive, but the corresponding quadratic coefficients of regression were negative. On the other hand, although the linear coefficients of regression of milk yield and fat yield on the age of dam were positive for twin births, but the corresponding linear coefficients of regression of milk fat percentage on the age of dam were negative for twin calvings (Table 6). The significant positive linear and quadratic regressions of age of dam showed that the increase in the age of dam or quadratic effect of age (age $\times$ age) can be caused an increase in milk yield, fat yield or milk fat percentage of dairy cows. But, the negative coefficients indicated that increase in the age of dam or quadratic effect of age caused decrease in the productive performance of dairy cows.

Continued increases in milk production over the last two decades in dairy herds have been associated with an increase in twinning rate (KINSEL et al. 1998, WILTBANK et al. 2000). WILTBANK et al. (2000) proposed that high milk production increases steroid metabolism as a result of an increased blood flow to the digestive tract and the liver. The 
subsequent metabolism of the steroid estradiol slows down the natural decline in $\mathrm{FSH}$, which means that follicles have more time to undergo physiological changes before ovulation (MATTIOLI 1996, WILTBANK et al. 2000, KANITZ et al. 2001). A positive association between milk production and twinning in dairy cattle has been observed in some studies (KINSEL et al. 1998, NIELEN et al. 1989), but not in others (BELL and ROBERTS 2007, DELUYKER et al. 1991). However, effects of milk production have been reported when comparing dams carrying or calving twins with their no twinning herdmates.

Table 4

Least-squares means and their standard errors for 305-d milk yield, milk fat yield and milk fat percentage of Holstein cows according to the effects fitted into the statistical models

Least-squares means und Standardfehler der Milchleistungen bei verschiedenen Einflussgrößen

\begin{tabular}{lcccc}
\hline Effect & Class & Milk yield, kg & Fat yield, $\mathrm{kg}$ & Fat percentage, $\%$ \\
\hline Parity & 1 & $6687.01 \pm 18.29^{\mathrm{d}}$ & $193.49 \pm 0.89^{\mathrm{d}}$ & $2.91 \pm 0.01^{\mathrm{c}}$ \\
& 2 & $7333.99 \pm 17.87^{\mathrm{b}}$ & $211.72 \pm 0.87^{\mathrm{c}}$ & $2.91 \pm 0.01^{\mathrm{c}}$ \\
& 3 & $7563.66 \pm 17.89^{\mathrm{a}}$ & $220.51 \pm 0.88^{\mathrm{a}}$ & $2.94 \pm 0.01^{\mathrm{b}}$ \\
Calf number & $=4$ & $7301.74 \pm 17.89^{\mathrm{c}}$ & $215.17 \pm 0.93^{\mathrm{b}}$ & $2.98 \pm 0.01^{\mathrm{a}}$ \\
& 1 & $6976.70 \pm 16.83^{\mathrm{b}}$ & $208.05 \pm 0.82^{\mathrm{b}}$ & $2.93 \pm 0.01^{\mathrm{b}}$ \\
Calving year & 2 & $7369.66 \pm 19.80^{\mathrm{a}}$ & $209.71 \pm 0.96^{\mathrm{a}}$ & $2.95 \pm 0.01^{\mathrm{a}}$ \\
& 1 & $6343.74 \pm 18.43^{\mathrm{c}}$ & $187.46 \pm 0.86^{\mathrm{c}}$ & $3.00 \pm 0.01^{\mathrm{a}}$ \\
& 2 & $6978.65 \pm 16.54^{\mathrm{b}}$ & $207.10 \pm 0.81^{\mathrm{b}}$ & $3.00 \pm 0.01^{\mathrm{a}}$ \\
Season of calving & 1 & $7041.05 \pm 17.94^{\mathrm{b}}$ & $201.83 \pm 0.87^{\mathrm{d}}$ & $2.88 \pm 0.01^{\mathrm{b}}$ \\
& 2 & $7694.47 \pm 16.28^{\mathrm{a}}$ & $220.45 \pm 0.82^{\mathrm{a}}$ & $2.091^{\mathrm{c}}$ \\
& 2 & $6975.72 \pm 17.87^{\mathrm{c}}$ & $206.57 \pm 0.87^{\mathrm{c}}$ & $2.99 \pm 01^{\mathrm{a}}$ \\
& 3 & $7303.92 \pm 18.09^{\mathrm{a}}$ & $215.57 \pm 0.87^{\mathrm{a}}$ & $2.98 \pm 0.01^{\mathrm{b}}$ \\
& 4 & $7298.32 \pm 19.16^{\mathrm{a}}$ & $207.92 \pm 0.87^{\mathrm{b}}$ & $2.87 \pm 0.01^{\mathrm{d}}$ \\
\hline
\end{tabular}

Least-squares means within a column that do not have a common superscript $(a-d)$ are significantly different $(P<0.05)$.

Table 5

Least-squares means and their standard errors for 305-d milk yield, milk fat yield and milk fat percentage for single and twin births of Holstein cows according to the effects fitted into the statistical models

Least-squares means und Standardfehler der Milchleistungen bei Einlings- und Zwillingsgeburten bei verschiedenen Einflussgrößen

\begin{tabular}{|c|c|c|c|c|c|c|c|}
\hline \multirow{2}{*}{ Effect } & \multirow{2}{*}{ Class } & \multicolumn{2}{|c|}{ Milk yield, kg } & \multicolumn{2}{|c|}{ Fat yield, kg } & \multicolumn{2}{|c|}{ Fat percentage, \% } \\
\hline & & Single & Twin & Single & Twin & Single & Twin \\
\hline \multirow[t]{4}{*}{ Parity } & 1 & $6688.4 \pm 17.7^{d}$ & $6825.1 \pm 80.2^{c}$ & $193.5 \pm 0.9^{\mathrm{a}}$ & $196.8 \pm 3.5^{\mathrm{d}}$ & $2.91 \pm 0.01^{c}$ & $2.98 \pm 0.04^{\mathrm{a}}$ \\
\hline & 2 & $7340.9 \pm 17.3^{b}$ & $7501.9 \pm 71.3^{b}$ & $211.9 \pm 0.8^{b}$ & $212.6 \pm 3.1^{c}$ & $2.91 \pm 0.01^{c}$ & $2.91 \pm 0.04^{b}$ \\
\hline & 3 & $7571.4 \pm 17.6^{a}$ & $7798.3 \pm 70.5^{\mathrm{a}}$ & $220.8 \pm 0.9^{b}$ & $225.8 \pm 3.1^{\mathrm{a}}$ & $2.94 \pm 0.01^{b}$ & $2.93 \pm 0.04^{b}$ \\
\hline & $>=4$ & $7306.9 \pm 18.8^{c}$ & $7521.2 \pm 74.4^{b}$ & $215.3 \pm 0.9^{c}$ & $218.0 \pm 3.3^{b}$ & $2.98 \pm 0.01^{\mathrm{a}}$ & $2.99 \pm 0.04^{\mathrm{a}}$ \\
\hline \multirow[t]{3}{*}{ Calving year } & 1 & $6342.0 \pm 15.5^{c}$ & $6687.9 \pm 399.6^{c}$ & $187.6 \pm 0.9^{c}$ & $184.9 \pm 2.5^{c}$ & $3.00 \pm 0.01^{\mathrm{a}}$ & $3.02 \pm 0.04^{\mathrm{a}}$ \\
\hline & 2 & $6974.1 \pm 16.3^{b}$ & $7300.6 \pm 403.2^{b}$ & $206.9 \pm 0.8^{b}$ & $212.3 \pm 2.6^{b}$ & $3.00 \pm 0.01^{\mathrm{a}}$ & $2.94 \pm 0.03^{b}$ \\
\hline & 3 & $7694.6 \pm 18.2^{\mathrm{a}}$ & $7989.2 \pm 396.3^{a}$ & $220.4 \pm 0.8^{\mathrm{a}}$ & $223.1 \pm 3.3^{\mathrm{a}}$ & $2.88 \pm 0.01^{b}$ & $2.92 \pm 0.03^{b}$ \\
\hline \multirow[t]{4}{*}{ Season of calving } & & $7040.5 \pm 17.4^{b}$ & $7357.8 \pm 70.8^{b}$ & $201.8 \pm 0.9^{d}$ & $203.0 \pm 3.1^{c}$ & $2.89 \pm 0.01^{c}$ & $2.89 \pm 0.04^{b}$ \\
\hline & 2 & $6976.4 \pm 17.3^{c}$ & $7258.2 \pm 70.3^{c}$ & $206.5 \pm 0.9^{c}$ & $208.2 \pm 3.1^{\mathrm{b}}$ & $2.99 \pm 0.01^{\mathrm{a}}$ & $3.01 \pm 0.04^{\mathrm{a}}$ \\
\hline & 3 & $7302.1 \pm 17.3^{\mathrm{a}}$ & $7655.6 \pm 70.7^{a}$ & $215.5 \pm 0.9^{\mathrm{a}}$ & $218.4 \pm 3.1^{\mathrm{a}}$ & $2.98 \pm 0.01^{b}$ & $3.00 \pm 0.04^{\mathrm{a}}$ \\
\hline & 4 & $7296.8 \pm 17.3^{a}$ & $7634.8 \pm 71.1^{\mathrm{a}}$ & $207.9 \pm 0.9^{b}$ & $209.1 \pm 3.1^{\mathrm{b}}$ & $2.87 \pm 0.01^{d}$ & $2.88 \pm 0.04^{b}$ \\
\hline
\end{tabular}

Least-squares means within a column that do not have a common superscript $(a-d)$ are significantly different $(P<0.05)$. 
Table 6

Coefficients of regression and their standard errors (SE) of 305-d milk yield, milk fat yield and milk fat percentage on the linear and quadratic effects of age of dam for all calvings (single and twin), single or twin births of Holstein dairy cows

Regressionskoeffizienten und SE der Milchleistungen abhängig vom Alter der Mütter und der Geburtenform

\begin{tabular}{lcccl}
\hline Item & Trait & Effect & Coefficient of regression* & \multicolumn{1}{c}{ SE } \\
\hline Single and twin births & Milk yield & Age & 52.79 & 0.41 \\
& & Age $\times$ Age & -0.38 & 0.003 \\
& Fat yield & Age & 1.63 & 0.02 \\
& & Age $\times$ Age & -0.01 & 0.0002 \\
& Fat percentage & Age & 0.002 & 0.0002 \\
& & Age $\times$ Age & -0.000004 & 0.000001 \\
Single births & Milk yield & Age & 52.94 & 0.42 \\
& & Age $\times$ Age & -0.38 & 0.003 \\
& \multirow{4}{*}{ Fat yield } & Age & 1.64 & 0.02 \\
& Fat percentage & Age $\times$ Age & -0.01 & 0.0002 \\
& & Age & 0.002 & 0.0003 \\
& Milk yield & Age $\times$ Age & -0.000005 & 0.000002 \\
& & Age & 46.99 & 2.65 \\
Twin births & Age $\times$ Age & -0.34 & 0.02 \\
& Fat yield & Age & 1.21 & 0.12 \\
& \multirow{2}{*}{ Fat percentage } & Age $\times$ Age & -0.008 & 0.0009 \\
& & Age & -0.003 & 0.0001 \\
& & Age $\times$ Age & 0.00003 & 0.00001 \\
\hline
\end{tabular}

*All of coefficients of regression were significant at $P<0.05$. SE standard error

The practical implication of the relationship between milk production and twinning in dairy cattle is important because current dairy-management strategies aim to maximize milk production per cow in the dairy industry. If twinning is related to milk production, this increase would not be unexpected considering the increases in milk production per cow over the years as a result of genetic selection and artificial insemination. Successful dairy cattle production will require changes in management to address problems of increased perinatal calf mortality and maybe other postpartum problems related to twinning. Key changes in management may include diagnosis of twin vs. single pregnancy and modification of nutrition for cows bearing or suckling twins. Assistance at calving for cows carrying twins may reduce complications associated with dystocia and may reduce economic losses by reducing the rate of neonatal calf mortality.

\section{References}

Bell MJ, Roberts DJ (2007) Effect of twinning on the feed intake, performance and health of dairy cows. Livest Sci 107, 274-81

Bicalho RC, Galvão KN, Cheong SH, Gilbert RO, Warnick LD, Guard CL (2007) Effect of stillbirths on dam survival and reproduction performance in Holstein dairy cows. J Dairy Sci 90, 2797-803

Cady RA, Van Vleck LD (1978) Factors affecting twinning and effects of twinning in Holstein dairy cattle. J Anim Sci 46(4), 950-6

Day JD, Weaver LD, Franti CE (1995) Twin pregnancy diagnosis in Holstein cows: Discriminatory powers and accuracy of diagnosis by transrectal palpation and outcome of twin pregnancies. Can Vet J 36, 93-7

Deluyker HA, Gay JM, Weaver LD, Azairi AS (1991) Change of milk yield with clinical diseases for a high producing dairy herd. J Dairy Sci 74, 436-45 
Fricke PM (2001) Review: Twinning in dairy cattle. Prof Anim Sci 17, 61-7

Ghavi Hossein-Zadeh N, Nejati-Javaremi A, Miraei-Ashtiani SR, Kohram H (2008) An observational analysis of twin births, calf stillbirth, calf sex ratio, and abortion in Iranian Holsteins. J Dairy Sci 91, 4198-205

Görlich L, Wollert J, Karge U, Heine C (1989) Effect of twinning on calving and growth parameters in beef calves. Arch Tierz 32, 535-43 [in German]

Hansen M, Misztal I, Lund MS, Pedersen J, Christensen LG (2004) Undesired phenotypic and genetic trend for stillbirth in Danish Holsteins. J Dairy Sci 87, 1477-86

Heins BJ, Hansen LB, Seykora AJ (2006) Calving difficulty and stillbirths of pure Holsteins versus crossbreds of Holstein with Normande, Montbeliarde, and Scandinavian Red. J Dairy Sci 89, 2805-10

Hosmer D, Lemeshow S (2000) Applied Logistic Regression. 2nd ed Wiley-Interscience, New York, USA

Kanitz W (2003) Follicular dynamic and ovulation in cattle - a review. Arch Tierz 46, 187-98

Kanitz W, Brüssow KP, Becker F, Torner H, Schneider F, Kubelka M, Tomek W (2001) Comparative aspects of follicular development, follicular and oocyte maturation and ovulation in cattle and pigs. Arch Tierz 44 Special Issue, 9-23

Kinsel ML, Marsh WE, Ruegg PL, Etherington WG (1998) Risk factors for twinning in dairy cows. J Dairy Sci 81, 989-93

Kirkpatrick BW (2002) Management of twinning cow herds. J Anim Sci 80 (E. Suppl. 2), E14-E18

Komisarek J, Dorynek Z (2002) Genetic aspects of twinning in cattle. J Appl Genet 43, 55-68

Mattioli M (1996) Molecular aspects of gonadotropin induced oocyte maturation. Arch Tierz 39 Special Issue, 31-41

Mee JF (1991) Perinatal calf mortality-recent findings. Ir Vet J 44, 80-3

Meyer CL, Berger PJ, Koehler KJ, Thompson JR, Sattler CG (2001) Phenotypic trends in incidence of stillbirth for Holsteins in the United States. J Dairy Sci 84, 515-23

Nielen M, Schukken YH, Scholl DT, Wilbrink HJ, Brand A (1989) Twinning in dairy cattle: A study of risk factors and effects. Theriogenology 32, 845-62

Ryan DP, Boland MP (1991) Frequency of twin births among Holstein-Friesian cows in a warm dry climate. Theriogenology $36,1-10$

SAS Institute (2002) User's Guide: Statistics, Version 9.1 Edition. SAS Inst. Inc. Cary, NC, USA

Silva del Río N, Stewart S, Rapnicki P, Chang YM, Fricke PM (2007) An observational analysis of twin births, calf sex ratio, and calf mortality in Holstein dairy cattle. J Dairy Sci 90, 1255-64

Simensen E (1982) An epidemiological study of calf health and performance in Norwegian dairy herds. I. Mortality: Literature review, rates and characteristics. Acta Agric Scand 32, 411-9

Syrstad $O$ (1974) Relationship between twin births and milk production in dairy cattle. Meldinger fra Norges Landbrukshøgkole 53, 5

Wiltbank MC, Fricke PM, Sangsritavong S, Sartori R, Ginther OJ (2000) Mechanisms that prevent and produce double ovulations in dairy cattle. J Dairy Sci 83, 2998-3007

Wollert J, Tilsch K (1988) Effect of maternal factor on performance testing results of young beef bulls. Arch Tierz 31, 537-43 [in German]

Received 6 June 2009, accepted 12 April 2010.

Corresponding author:

NAVID GHAVI HOSSEIN-ZADEH

email: nhosseinzadeh@guilan.ac.ir

Department of Animal Science, Faculty of Agriculture, University of Guilan, P. O. Box 41635-1314, Rasht, Iran 